\title{
能登地方に拈ける牛のパラインフルェンザ（3 型）について
}

\section{I . 発生状況ならびにその病因について \\ 祐泉 有* 石黒貞彦* 稲口利次* \\ (昭和 42 年 12 月 28 日受付)}

\section{はじめに}

石川県珠州市営放牧場およびその周辺の和牛に 1964 年以来多発し，莫大な損害をうけている牛の伝染性呼吸 器疾患について 1966 年末までの概要はすでに報告1 3) した通りである。すなわち私どもは本病はパラインフル エンザ 3 型ウイルスとグラム㓌性桿菌の合併による，い わゆる輸送熱 (Shipping fever) であることを明らかに し，その治療法について述べたが，今回はその後におけ る能登地方の本病の調査, 試験などについて報告する.

\section{1. 被害の概要につんて}

能登地方の本病による被害の主なるのは次の通りであ る.

1) 珠州市営放牧場：1966年までの被害については前 儿報告1)したが，1967 年は越冬牛 134 頭, 新入牧和牛 子牛 41 頭であった. その経過の概要は表 1 の通りであ り, 新入牧牛は全頭発症をみたが，その頭数の少ないこ とと治療方法の進歩により，秋口となり終息の形となっ た. 1968 年は越冬牛 130 頭, 7 月までに新入牧和牛子

表 1 珠州市営放牧場 1967 年度放牧経過表

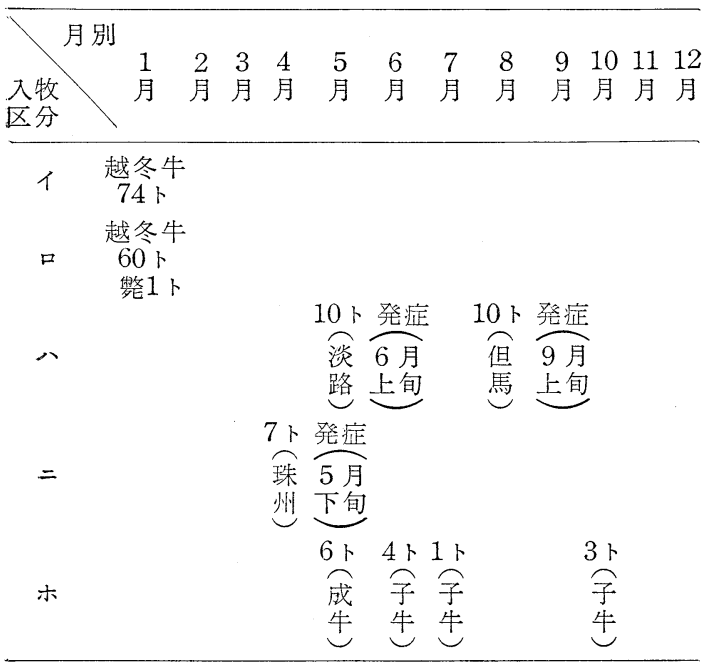

\section{経過所見}

八. 一般に軽症, 鼻漏少く, 下相約半数.

二. 半数重症, 一部下痢.

ホ。成牛は民間予託, 軽症.

* 石川県農業共済組合虺合会

日獣会誌

$21 \quad 647 \sim 652$

(1968)
牛 65 頭，その経過の概要は表 2 の通りで，前年とほぼ 同様の治療で発症後約 10 日という短期間の経過で治癒 した. 1964 年初発以来入牧緿頭 468 数頭の注とんぞ全 頭発症し，18頭 $(3.58 \%)$ の廢擎牛をみた。その内訳は 表 3 の通りである. 現在な和発病はくい止めていないが 治療法の進歩により経過は短縮され，廃整牛は皆無とな った。

2）珠州市上戸放牧場：本放牧場は民間経営であり， 市営放牧場より例年若干頭の牛の転入をらけるためか,

表 2 珠州市営放牧場 1968 年度放牧経過表

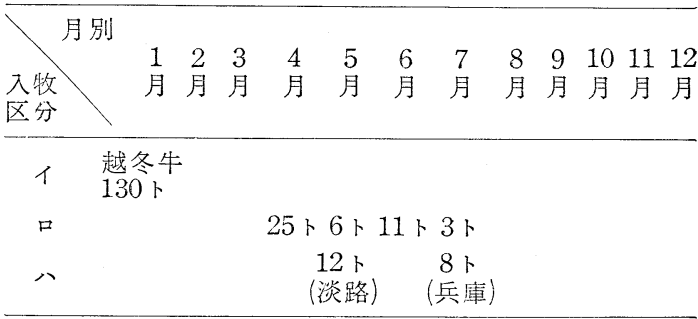

経過所見

口。本場生産子牛。咳欲，下痢。

八. 俥症.

表 3 珠州市営放牧場年度別経過表

\begin{tabular}{|c|c|c|c|c|c|c|c|}
\hline 年 度 & 1963 & 1964 & 1965 & 1966 & 1967 & 1968 & 計 \\
\hline 入牧頭数 & 32 & 195 & 71 & 96 & 41 & 65 & 500 \\
\hline 数 & 0 & $\begin{array}{r}\text { 重症 } \\
30 \\
\text { 中症 } \\
22 \\
\text { 軽症 } \\
140 \\
140\end{array}$ & $\begin{array}{r}\text { 重症 } \\
20 \\
\text { 中症 } \\
13 \\
\text { 軽症 } \\
38\end{array}$ & $\begin{array}{r}\text { 重症 } \\
8 \\
\text { 中症 } \\
15 \\
\text { 軽症 } \\
73\end{array}$ & $\begin{array}{r}\text { 重症 } \\
6 \\
\text { 中症 } \\
10 \\
\text { 径症 } \\
19\end{array}$ & $\begin{array}{r}\text { 重症 } \\
0 \\
\text { 中症 } \\
0 \\
\text { 軽症 } \\
60\end{array}$ & $\begin{array}{r}\text { 重症 } \\
64 \\
\text { 中症 } \\
60 \\
\text { 倝症 } \\
330\end{array}$ \\
\hline 㢣頭数 & 0 & 9 & 6 & 2 & 1 & 0 & 18 \\
\hline
\end{tabular}

储考：入牧牛は重症，当症のほかは喽症としてほと九ど 登症した。内治療を要したもの約半数。

表 4 珠州南上戸放牧場年变別経過表

\begin{tabular}{|c|c|c|c|c|c|c|}
\hline 年 度 & 1963 & 1964 & 1965 & 1966 & 1967 & 1968 㖕 \\
\hline 入牧頭数 & 0 & 35 & 80 & 130 & 145 & 140 \\
\hline 発病頭数 & 0 & 重症1 & 重症1 & 重症10 & 重症21 & 10 重症 40 \\
\hline 廃整頭数 & 0 & 1 & 5 & 2 & 2 & 10 \\
\hline
\end{tabular}

備考：入牧牛中南営放牧場より耐過牛として転入を受け たものを含む。従って発病頭数は重症のもののみ記 入. 
能登地方に打ける牛のパラインフルエンザ（ 3 型）について

臨床的には市営放牧場のものと同一の疾病の発生を みている、しかしウイルスに対する究明はおこなっ ていない. 細部は表 4 の通りで 1964 年以来総入牧 頭数 530 頭の大部分が罹患し, 内廃整牛 10 頭(1.89 \%)である.な持特異な事項として 1967 年には本 放牧場生産の子牛 7 頭全部に生後 1 週間程度で白痢 症の発生をみたが，本症と関係があるかどうか不明 である、本放牧場については1968 年7月にいたる もな敛嗽などを発するものあり，完全には終息し ていない.

3）槄至郡門前町中谷内放牧場：本放牧場は民間 経営であり，珠州市とは遠隔の地にあるが，1967年 6 月放牧中の 1 群和牛子牛 18 頭全部に珠州市の牛 と同一症状の発病をみた. 本牛群中に珠州市より䎐 入をらけた牛があり, 放牧前舎飼中に感染波及した 疑いがもたれる. 本地区は本病に対し未経験の地で あり,早期受診を欠いたため, 治療に長期間を要し, 本病のため 1 頡, 平病合併頭の擎死をみ, 一応終息 した. ウイルス検索成績は表 5，6の通りである. 1968 年は 5 月 10 頭入牧, 内 1 頭呼吸器疾患の発生 をみたが，その後発生していない。

4) 瞗至郡柳田村繁殖センター：1968 年 3 月 12 日〜14日間兵庫県より和牛子牛 60 頭を導入し, 一 応各農家に分散, 飼育し 17 日センターに収容し た.放牧にいたらず同月 14 日頃より逐次発熱, 鼻 漏，咳嗽をあらわし全頭におよんだ. 本地区る未経 験地のため頭初治療方針をたてるに若干の日数を要 し，結局 3 頭の整死をみ，終息にいたるまで 2 ケ月 を要した。ウイルス, 細菌に対する検索成績は表 7 の通りである. 本牛群は他の能登地区の発病牛とは 交流はなく，また現地においては潜伏期間なく到着 直後より発病をみていることから, 病毒を保有した ものが導入された疑いがもたれる.

5）珠州市大谷放牧場：1968年4月12日～14日間 能登各地区より和牛子牛 15 頭を入れ，5月 6 日放 牧したところ，5月中旬より珠州市営放牧場と同一 症状のものが発生し, 全頭におよんだので 5 月25日 収牧舎飼とした、本放牧場は未経験地で発見が遈れ たため, 重症のもの 5 頭を算えたが治療の適切をえ たためか，廃整牛なく 1 ケ月余の経過で終息した。本牛 群についてはウイルス, 細菌学的究明は抗こなっていな いが，珠州市などの牛購入先で病毒の感染をらけたもの が環境の変化により発病し, 逐次他に波及したとみるの が適当であろら。な拉本牛収容の牛舎には未経験成牛 10 頭余を㢣畜しているが，感染の機会あるにもかかわらず
表 5 パラインフルェンザ 3 型ウイルスに対す る $\mathrm{H}$ I 抗体価

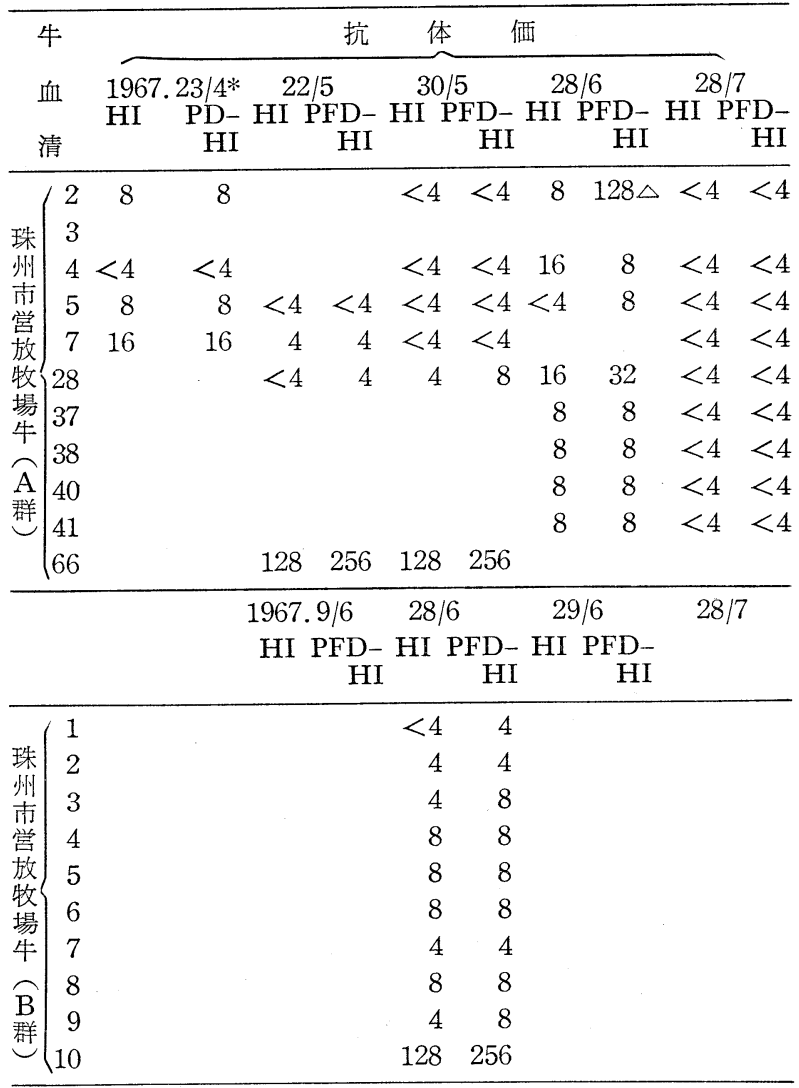

\begin{tabular}{|c|c|c|c|c|c|}
\hline & 1 & 8 & 16 & \multicolumn{2}{|c|}{$\geqq 1024 \geqq 1024$} \\
\hline 閒 & 2 & $<4$ & $<4$ & 8 & $32 \triangle$ \\
\hline $\begin{array}{l}\text { 前 } \\
\text { 町 }\end{array}$ & 3 & 8 & 8 & 16 & $128 \triangle$ \\
\hline 中 & 4 & 8 & 8 & 32 & $128 \triangle$ \\
\hline 谷 & 5 & $<4$ & $<4$ & 8 & 8 \\
\hline $\begin{array}{l}\text { 内 } \\
\text { 放 }\end{array}$ & 9 & & & \multicolumn{2}{|c|}{$1024 \geqq 1024$} \\
\hline 牧 & 14 & & & 256 & $\geqq 1024 \triangle$ \\
\hline 場 & 18 & & & 64 & $256 \triangle$ \\
\hline 牛 & 21 & & & 16 & 16 \\
\hline
\end{tabular}

* 正常馬血清を添加したもの. 最近の感染のあったものは 2 $\sim 3$ 倍以上の力価を示す ( $\triangle$ 印)

A 群は病性鑑定のため農林省家畜衛生試験場に材料を送付し た群。

B群は農林省の調査に応し材料を送付した群.

$\mathrm{A}$ 群は $(2,3,4,5,7,28)(37,38)(40,41)(66)$ の 4 群 に分け飼育した。

発病をみなかった。

6）珠州市一円の一般農家：これらについては前回も ふれたが, 和牛, 乳牛に散発している.しかしながら一 戸当りの飼育頭数が少ないため一般には目立たないが， かなりの損害をらけていることは事実であり, 全般的に は未だ終息に至っていない。これらについては臨床的に 
表 6 アデノウイルス袋井株に対する H I 抗体価

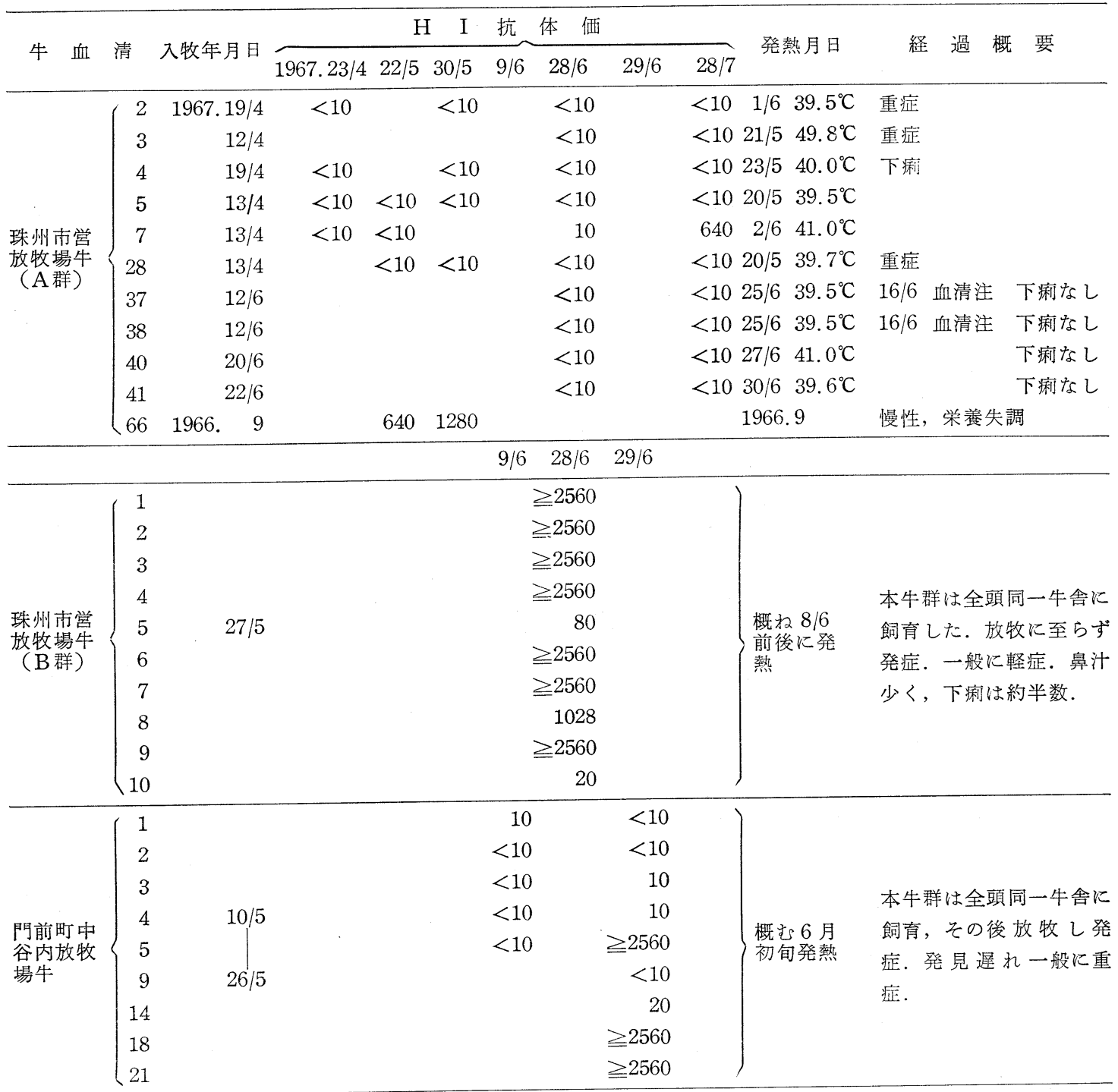

本表は表 5 の牛と同一牛である。

は珠州市営放牧場と同一症状であるが, ウイルス, 細菌 学的究明はおこなっていない。

\section{2. 症状の概要}

臨床所見としては概ね前回報告の通り呼吸器症状を主 徵とし, 栄養衰退する。しかし生群により発症程度, 経 過に若干の差異がある.これは病原ウイルス, 細菌の種 類, 動き方および治療の遅速などが関係するものと思わ れる. 全般的には 1966 年以前の症状は附随的に重度の 下疮症状がみられたが，当時は血清学的にはアデノウイ ルスを明らかにすることは出来なかった. 1967年以降は アデノウイルスを証明されるにもかかわらず，放牧場生 産子牛以外はどの牛群も下痢症状は重くはない.1967年
以降の主な生群の症状は次の通りである.

1）珠州市営放牧場：1967年 4月入牧A牛群（表 5,6 参照） 7 頭は（パラインフルエンザ 3 型ウイルス，アデ ノウイルス混合感染例) 発症まで 1 ケ余を要したが, 症状は一般に重く, 発熱, 結膜不潔带赤色, 発咳, 鼻漏 などをあらわした。

1967 年 8 月入牧B牛群（表 $5 ， 6$ 参照）10頭は（パラ インフルェンザ 3 型ウイルス, アデノウイルス混合感染 例) 放牧にいたらずして約 12 日で発症した。発熱, 結 膜不潔帯赤色, 発咳, 少量の白色鼻漏, 下痢は半数にみ られ軽度, アデノウイルスの抗体価上昇（入牧 1 ケ月後 の検査成績）にもかかわらず下痢が軽度である。 
能登地方に拈ける牛のパラインフルエンザ（3 型）について

表 7 柳田村繁殖センター牛, 可検血清のウシ アデノウイルス拉よびパラインフルエンザ 3 型ウイルスに対する抗体調査表(1968.3〜4)

\begin{tabular}{|c|c|c|c|c|c|c|}
\hline \multirow{3}{*}{$\begin{array}{c}\text { 牛 } \\
\text { 血 } \\
\text { 清 }\end{array}$} & \multicolumn{3}{|r|}{$\mathrm{H}$} & 抗 体 & 価 & \\
\hline & \multicolumn{3}{|c|}{$\begin{array}{l}\text { アデノウイルス } \\
\text { 袋井株 }\end{array}$} & \multicolumn{3}{|c|}{ パラインフルェンザ 3 型 } \\
\hline & $\overparen{18 / 3}$ & $4 / 4$ & $26 / 4$ & $18 / 3$ & $4 / 4$ & $26 / 4$ \\
\hline 8 & $<10$ & 80 & & $<4(32) *$ & $4(32)$ & \\
\hline 9 & & & $<10$ & & & $\begin{array}{l}1024 \\
(\geqq 1024)\end{array}$ \\
\hline 12 & & & $<10$ & & & $\stackrel{256}{(\geqq 1024)}$ \\
\hline 15 & $<10$ & $<10$ & & $<4(4)$ & $16(64)$ & \\
\hline 19 & 10 & 10 & & $<4(4)$ & $32(128)$ & \\
\hline 21 & & $<10$ & $\geqq 2560$ & & & $(\geqq 1024$ \\
\hline 23 & $<10$ & $<10$ & $<10$ & $<4(<4)$ & $<4(128)$ & \\
\hline 30 & 10 & & & $<4(<4)$ & $<4(256)$ & \\
\hline 31 & 10 & 160 & & $256(256)$ & $128(128)$ & \\
\hline 32 & 10 & 320 & & $<4(<4)$ & $64(128)$ & \\
\hline 41 & $<10$ & 20 & & $<4(4)$ & $<4(8)$ & $64(128)$ \\
\hline 44 & 10 & 160 & & $<4(<4)$ & $<4(32)$ & $\begin{array}{l}512 \\
(\geqq 1024)\end{array}$ \\
\hline 52 & & & 160 & & & $(\geqq 1024$ \\
\hline 59 & $<10$ & 160 & & $<4(<4)$ & $<4(8)$ & \\
\hline 乳 1 & & & $>2560$ & & & $\stackrel{512}{(\geqq 1024)}$ \\
\hline 乳 2 & & & $<10$ & & & $\stackrel{512}{(\geqq 1024)}$ \\
\hline
\end{tabular}

1) ウシアデノウイルスでは 10 倍以上を抗体陽性パラ インフルェンザ 3 型ウイルスでは 4 倍以上を抗体陽性 とする。

2) *( ) は正常ウマ生血清加H I 価を示す.

3）本牛は $12 / 3 \sim 14 / 3$ 間兵庫県より導入した。

1968 年 5 月入牧牛群 12 頭は（ウイルス未検査）前記 B 牛群が他に移動した後, 数ケ月を経てその牛舎を消毒 の上収容した，入牧後放牧にいたらずして約 10 日で発 症した. 発熱, 結膜不潔帯赤色, 発咳, 極少量の白色鼻 漏を出す. 発見と同時に治療したためか一般に軽症で約 10日間の経過で治癒した。栄養の衰退は軽度である。

なお 1968 年本放牧場に耐過牛より子牛 45 頭が生産 された。これらはいずれも発熱, 咳嗽, 鼻漏などをみと めたほか下痢が重度であった。

2）珠州市上戸放牧場：1964～1968年間収容牛につい ては (ウイルス未検査) 珠州市営放牧場牛と同一症状で あるが, 1967 年においては生後 12 年末満のものがと くに重度で, 栄養衰退, 鼻漏, 咳嗽, 湿性ラッセル, 下 痢をあらわした．本放牧場生産子牛は生後間もなく白痢 症に罹患し, 発育不良となった。

3）鳳至郡門前町中谷内放牧場：1967 年 6 月入牧 18 頭は（パラインフルェンザ 3 型ウイルス，アデノウイル
ス混合感染例) 病牛の発見，治療が遅かったため，一般 に重症で発熱, 食慾不振, 結膜不潔帯赤色, 発咳, 白色 鼻漏, 湿性ラッセル, 軟便の症状をあらわし, 栄養は衰 退した。

4）鳳至郡柳田村繁殖センター：1968 年 3 月導入 60 頭は (パラインフルエンザ 3 型, ウイルスアデノウイル ス混合感染例) 到着直後より発熱, 食照不振, 咳嗽, 白 色鼻漏, 湿性ラッセルをあらわし, 一般に重症で栄養は 衰退した。

5）珠州市大谷放牧場：1968 年 4 月入牧 15 頭は（ウ イルス末検査）現地購入子牛のみであるが発症した。放 牧後発見したため治療が遅れ，発熱，食慾不振，咳嗽， 白色鼻漏, 湿性ラッセル, 栄養衰退著るしく症状は一般 に重度であった。

\section{3. 病理解剖括よび組織学的検查所見}

最近では本病による廃斃牛がなくその機会をえられな かったが，たまたま柳田村繁殖センタ一整死牛（発病後 概ね 2 週間） 2 頭について执こなった。 その所見は次の 通りである.

1) 病理解剖学的所見：病変部は両者注添同様であっ て, 肺臓の変状が最も著しかった．肺臓の前 $2 / 3$ は帯紫 赤色を呈し硬度を増し，肝变化の所見がみられ，健康部 との境界明膫, 気管粘膜は点状, 樹枝状の充出血を夕, 切断すると血様液を漏出し, 気管支内より黄白色の膿汁 を漏出する。しかしその量は以前珠州市営放牧場整牛に みたものよりやや少ない. 第 1 第 3 胃は内容硬固で, 粘膜は針頭大出血をところどころにみられる.

2) 病理組織学的所見: 肺臓の細小気管支上皮細胞は 腫大増殖し, 破壞, 離脱するもの多く, 内腔に粘液, 多 数の単核細胞, 多核巨細胞㧊よび少数の好中球を充して いる，肺胞壁は小葉性に破壞され，内腔に粘液，赤血球 および少数の単核細胞がみられ，破壞された壁部には単 核細胞, 多核巨細胞, 好中球など多数がみられる. 血管 内膜はところどころ破壊され中膜細胞の露出がみられ る.

以上の所見は 1965 年に珠州市営放牧場整牛（発病後 1 ケ ケ後）におこなった病理所見とほぼ同様である が, 今回のものは剖検上細小気管支内の膿汁が少ないこ と, 組織学的には破壊された肺胞内の単核細胞が少な く, 赤血球が多く見出される点が異なる.このことは発 病後日浅くして繁死, 剖検した結果とも考える.なお封 入体は見出すことは出来なかった.

\section{4. 病症の経過について}

私どもは経験上, 入牧より発症まで概ね 10 日前後で あることがわかり, 発症日を予測出来ることから, 珠州 市営放牧場など経験地では発症 (初期は結膜充血, 発熱 のみ）と同時に治療を抗こならため, 概ね2 2 週間以内で 完治している、しかしながら細部について検討すると, 
牛個体により数日の経過にて治癒し再び発熱しないも の, 治療により一たん下熱するも再び発熱し再度の治療 により治癒するものなど差異がある. 未経験地では通常 発見, 処置が達れ 2 週間以上の経過をたどるものが多 い, 重症となり湿性ラッセル, 栄養衰退などあらわした ものは抗生物質の応用により一時は下熱するも上昇を繰 返えし，治痖まで $1 〜 2$ ケ月の経過をたどるようであ る.

これら病症の経過日数は個体の抵抗力, ウイルス, 細 菌の種類，治療方法などが関係することで一概にのべる ことは出来ないが, 現在治療方法の改善進歩により, 以 前より一般に経過が短くなったことは事実で, かなり重 症で以前梅死の転帰をとったと又られるものでも現在 は治癒せしめることが出来るよらになった．ただ獘死牛 は剖検上肺臓が化膿性炎症をおこし， $2 / 3$ 以上が肝変化 していることから，この程度になったものは現在でも治 癒の見込みは活とんどないと考劣る。

\section{5. 病因の探究}

1) ウイルスと本症との関係.

ウイルスについてはパラインフルェンザ型ウイルスが 関係していることを前回報告1)したが，1967年はさらに 農林省家畜衛生試験場に血液を送り, 本ウイルスおよび ，これまでしばしば放牧当初混合感染のみられているア デノゥイルス5)についても鑑定を求めた。 その結果は表 5,6の通りである.

(1) パラインフルェンザ 3 型ウイルス: 珠州市営放牧 場(表 5,6 A 群牛)中に抗体の上昇するものがあり (No. 2, 28)このことから 1967 年はこのウイルスは一応動い たものと考兄られるが，抗体の上り方は全体に弱いこと から，この感染ははげしいものではないと判断された。

珠州市営放牧場（表 5,6 B 群牛)はすべて抗体をもっ ていたものの, 一般に低く, かつ正常血清添加によって 力価の差のないことから，この感染は古いものと考光ら れた。
鳳至郡門前町中谷内放牧場牛 9 (表 5,6 ) では明らか に上昇がみられ，乙かも前後血清のないものも，正常血 清のないものも, 正常血清の添加による力価の上昇が著 るしいことから, この抗体の上昇と病性はよく一致し, 病牛の呼吸器症状はこれによったと考兄られた.

鳳至郡柳田村繁殖センター牛（表 7) は 16 頭中全例 抗体陽性であり， うち 9 頭 (No. 12，15，19，23，30, $32 ， 41 ， 44 ， 49)$ は抗体価の有意の上昇がみら机た。

（ロ）アデノウイルス：珠州市営放牧場（表 5, $6 \mathrm{~A}$ 群 牛)に和いては (No.7) 飞の久感染が夕られた。

珠州市営放牧場（表 5, 6 B 群牛）では汪とんど全例高 い抗体を示しておうり, 入牧時の血清がないので, 正確に は不明であるが抢そらく本ウイルの感染があったものと 考光られる。

鳳至郡門前町中谷放牧場牛（表 5,6)飞执いては明ら かな上昇を示して抢り, 対でないものも (No. 18，21) 抗体価の高いことから, 最近の感染と考光られ, この牛 群では前後して少なくと 2 つのウルスが明らかに動 いたことを示している.

鳳至郡柳田村繁殖センター牛（表 7) では 16 頭中 11 頭抗体陽性であり, うち 7 頭 (No. 8, 21，31，32，41, 44，59）は抗体価の有意の上昇がみられた。すなわち, この牛群では両ウイルスのいずれか, または混合感染が 扣きたものと思われる。

2) 病牛肺炎患部より分離した, グラム陰性桿菌と本 症との関係.

（亿） 細菌の同定：前回報告1)の発病試験に用いたグラ ム陰性桿菌は死減したが, その後私ぞもは珠州市営放牧 場, 上戸放牧場, 柳田村繁殖センターの本病による擎牛 の肺炎患部より採取した膿汁を，ハートインフュージョ ン寒天培地に培養し, 光たコロニーを S S 寒天外各種培 養基补よび桾分解能等約 50 種類の培養, 生化学的検査 をおこなったところ, 次の細菌であることがわかった。

また，その感受性試験の結果は表 8 の通りである.

表 8 感受性陚験成績表

\begin{tabular}{|c|c|c|c|c|c|c|c|c|c|c|c|c|}
\hline 菌 種 & $\mathrm{PC}$ & $\mathrm{EM}$ & OM & LM & $\mathrm{CM}$ & $\mathrm{T} \mathrm{C}$ & $\mathrm{SM}$ & $\mathrm{KM}$ & C L & S X & 採取擎牛飼育牧場 & 採取年月日 \\
\hline Pseusomonas aeruginosa & - & - & - & - & + & + & + & + & + & + & 珠州市営放牧場 & 1966.10 .29 \\
\hline Pseudomonas aeruginosa & - & - & - & - & + & + & + & + & + & - & 珠州市営放牧場 & 1967. 1.29 \\
\hline Proteus & - & - & - & - & + & + & + & + & - & + & 珠州市上戸放牧場 & 1966.12 .17 \\
\hline Alcaligenes faecalis & - & + & + & - & + & + & + & + & + & - & 珠州市営放牧場 & 1967. 1.29 \\
\hline Escherichia Coli & - & - & - & - & + & + & + & + & + & - & 柳田村繁殖センター & 1968. 4. 4 \\
\hline Haemophilus & - & + & + & + & + & + & + & + & + & + & 柳田村繁殖センター & 1968. 4. 4 \\
\hline Alkalescens Dispar & - & + & + & + & + & + & + & + & - & - & 柳田村繁殖センター & 1968. 4. 4 \\
\hline
\end{tabular}

ディスクは"栄研ディスク”による. 培地はハートインフュージョン寒天培地. SXについてはミューラヒントン

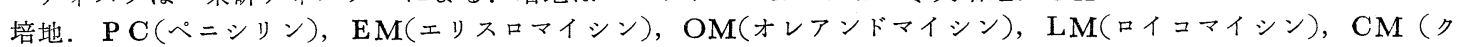
ロラムフェニコール), TC (テトラサイクリン), $\mathrm{SM}$ (ジヒドロストレプトマイシン), $\mathrm{KM}$ (カナマイシン), CL (コリスチン), S X (スルフィソキサゾール). 
能登地方における牛のパラインフルェンザ（3 型）について

珠州市営放牧場牛 $\left\{\begin{array}{l}\text { Pseudomonas aeruginosa. } \\ \text { Alcaligenes faecalis. }\end{array}\right.$

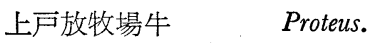

柳田村繁殖センター牛 $\left\{\begin{array}{l}\text { Escherichia coli. } \\ \text { Haemophilus. } \\ \text { Alkalescens Dispar. }\end{array}\right.$

な和例教を重ねる必要があるが，これを以て能登地区の 牛肺炎患部の菌種の一端を想像出来ると思う.

(口) 細菌の発症に対する役割についてこのことにつ いて次のことが認められた。

a) 廃整牛肺炎患部膿汁には必ず細菌が検出される.

b) ウイルス感染の疑いのない摘脾牛にこれら細菌の 一種（実験当時未同定であった）をハートインフュージ ョンブイョンに $24 \mathrm{~h}$ 培養しその $20 \mathrm{ml}$ を気管内に注入 し，寒気にさらしたが発病しなかった1).

c）本症潜伏期間中に，これら細菌制圧の目的で感受 性ある抗生物質を注射すると, 発症がウイルスのみによ ると思われる軽度の症状経過をとる。 また潜伏期間中に Kasugamycin $2 \mathrm{gr}$ の気管内注入を和こならと, 同群の 他の牛より潜伏期間を約 200 日間延長せしめる.

d）発症後感受性ある抗生物質の気管内注入をおこな らと，翌日ただちに下熱する。

上記の細菌はいずれも自然界に広く分布し，また呼吸 器内にも常在するものであり, 輸送, あるいはウイルス 感染など動物の抵抗力の低下により呼吸器, 消化器その 他藏器の炎症あるいは化膿性病変をあらわすことは一般 に認められているところであり，本症についても前記ウ イルス検索成績とあわせ考え，随伴菌として作用してい るものであろら。なお輸送熱の原因の一つとされている Pasteurella 菌は未だ証明されていない.

\section{6. 本病の伝染力などについて}

本病に污染された牛舎を 1 ケ年間比較的乾燥された状 態で放置し，再び健康牛 10 頭を収容したところ，10日 前後の潜伏期間を経て全牛発病をみた。また通常行なわ れる消毒薬液による牛舎消毒は徹底を望みがたく, 予防 的効果を現わしたことはない．従って一たん定着した病 毒の死隇は容易ならざることが感じられる. しかし，こ の種のウイルスや細菌の疫学には不明の点が多く, これ らの病原体は感染耐過した牛が健康保毒者になり得るこ とも考えられ，これらの問題の解明については将来の研 究をまたなければならない、また本病の伝染力について は流行熱のごとく激甚ではないが, 病牛と健康牛との接 触少よび人を介し間接的に伝染することは事実であり， これらの跡をたどることにより伝染経路を知ることが出 来る、ただ一たん完全に治癒したものは再び発症しない し，成牛は感染をらけているにもかかわらず発症しない ことが多い.

\section{7. 発病についての考察}

珠州市営放牧場その他能登一川の放牧場などに発生し ている牛の伝染性の化膿性気管支肺炎を主徵とする疾患 はパラフィンフルェンザ 3 型, ウイルスアデノウイルス が火付役となり，これに随伴菌としPseudomonas Aeruginosa 外数種のグラム陰性桿菌などが作用し, 発症して いるいわゆる輸送熱 (Shipping fever) であると考える. 牛群により症状に若干の軽重がみとめられるのは, これ ら起炎病毒などの動き方によるものであろら。な捋来 検査を進めるに従い, 他のウイルス, 細菌が追加される ことも考えられる.

発病牛は前飼育地においては臨床的にはなん等異常が なく（ウイルス保有の有整は不明）栄養状態も良好であ り，新飼育地に到着後発病するものである. 遠距離より 輸送をらけた子牛は, 到着後疲労によると考えられる軽 度の体温の上昇, 結膜やや充血をみるがその後 $2 \sim 3$ 日 で平熱に復し, 到着後 10 日前後の潜伏期で本病本来の 発熱その他の症状を現わすのを常とする，その誘因につ いては環境の変化が大きく作用することであ.これは牛 を悪環境下におくためという意味でなく，単に環境の変 化が牛に心理的に大きなストレスとなり，抵抗力を減退 せしめ，そのためそれまで潜伏状態で感染していたが勢 をたくましくし発病するということが考えられる。この ことは臨床的に健康な（ウイルスは保有の疑いあり）現 地産子牛を無污染牛舎（環境，飼育条件は悪くない）に 移動させるたのみで発症し，同牛群全部に波及した例 (大谷放牧場) でもわかる。すた本病は各放牧場に発生 しているものの，放牧に至らず舎飼間に発症している例 が多く，むしろ放牧そのものとは関係がなく，多頭飼育 が多発といら結果をまねていると考えられる。

\section{おわりに}

本症は前記の通りウイルス，細菌合併によるいわゆる 輸送熱 (Shipping fever) と考えられ，その伝染力は急激 ではないが，その伝染源が一たん放牧場などに定着した 場合容易に消滅しない，放牧場は事業の性質上相次て転 出, 転入等あり, 防疫は困難であり, また国内各地より 牛を集め放牧飼育する関係上, 病原もまた多種多様とな る恐れがある、これはあたかも戦時中豊橋陸軍補充馬廠 の軍馬に発生した豊橋病のごとき感がある。私どもは 1964年以来長年にわたる病因の探究により，概ねその全 ぼらを明らかにしたものと考学報告した。

終りに病性鑑定に多大のご援助とご指導を賜った家畜 葦生試験場大森技官，外関係各位に梁甚の感謝の意を表 します。

$$
\text { 文献 }
$$

1) 祐泉, 外：日獣会誌, 20,161 (1968)。2) 祐 泉, 外: 家畜診療, $60,4(1967)$. 3) 祐泉, 外：日 獣会誌, 20,430 (1967). 4) 家畜衛生試験場年報 : V 24 (1963).5）大森常良：日獣会誌，20,457 (1967). （英文抄録は 657 ページへつづく） 
資

離すること. 最低 30 日間の隔離の間に種々の予備検査 を行ない，かつ材料を採取し検査のため P I A D L (プ ラムアイランド) に送付すること.

4. プロバング用の材料と血清（少なくとも $15 \mathrm{cc}$ )を 隔離施設内で各動物から採取し, 血清反応, ウイルス分 離のため涷結してP I A D Lに送付すること.

5. 施設に隔離されたすべての輸出用牛は, 結核病およ びブルセラ病について要求された検査に適合すること.

6. 生産地施設における最低 30 日間の隔離をお文, 必要な検査を完了した動物は積出港にお打る検疫施設に 移動すること.その施設は動物が米国に輸出されるため に船舶に積みこまれる港にあり, 米国農務省により特に 認可されたものであること. 積出検疫施設では最低 30 日間動物をけい留し，その間毎日獣医官が検査を行なう こと.

7. 第 7 項に述べた検査材料の採取後少なくとも 60 日後に第 2 回のプロバング用の材料と血清を検疫中の各 動物から採取してP I A D Lへ送付すること.

8. 隔離または積出検疫の開始後に他の動物が加わっ た場合は，それまで実施した隔離または検疫は無効とす ること.

9. 積出港に和壮る最低 30 日間の検疫を終了し輸送 用の船舶に積みこむ直前に米国獣医官と日本獣医官は, 当該家畜が最低 60 日間（生産施設に乱ける 30 日閒の 隔離拉よび積出検疫に和ける 30 日間のけい留) 毎日獣 医検査をうけ，伝染病にかかっている疑いが全くなく， かつ, 判断しらる範囲に执いて伝染病に感染の機会のな かったことを証する健康証明書を発行すること.

10. 隔離施設から積出検疫施設へ, また積出検疫施設 から船舶への輸送車輛叔よび船舶は使用前にとのつど米 国獣医官の監督のもとに，清掃と消毒を行ならこと。

動物の輸送は, 米国獣医官の直接監督のもとに許可さ れた経路を直行して行ならこと．

(652ページよりつづく)
料

11. 隔離施設. 積出検疫拉よび米国への輸送船舶上で 使用するすべての乾草, わら, 飼料, 敷料その他これに準 ずる物は米国原産のものとし, 日本に直接積出され途中 で寄港しないこと、日本に打ける保管は，使用するまで 米国獣医官の監督のもとにあること.

12. 日本の港から米国に積出される動物の輸送に使用 する船舶には他の動物を積まないこと、船船は米国への 途中で寄港しないこと.

13. 米国獣医官は船舶が日本の積出港から出航後, 米 国の最初の港であるニューヨークに到着するまで乗船し ていること.

米国領海に入る前, 米国獣医官は航海中の観察にもと ついて米国領海に入ることを禁止されている伝染病の有 無について船長に報告すること.

14. 動物が施設内の隔離, 積出検疫あるいは米国への 輸送途中に伝染病を疑われる場合には，すべてまたは一 部の動物について不適格とすること.

口蹄疫その他の海外悪性伝染病が疑われる場合は, 船 舶の入港は拒否される.

15. 動物は輸入者の負担により少なくとも 30 日間二 ューヨーク検疫施設に沶いて検疫される.この期間毎日 獣医官による必要な検査を行なう。

I6. ニューヨーク検疫施設に到着後 15 日以後にプロ バング用材料と血清を採取し P I A D L に送付する.

17. 動物が輸入港に打ける検疫期間に伝染病にかかっ ていることが明らかになった場合，米国政府は補償金な しに全動物の受け入れを拒否し，かつ適当な廃棄処分を 行ならことが出来る。もし口蹄疫气の他海外悪性伝染病 が疑われる場合には，米国政府は補償金なしに全動物の 殺処分を行なら.

18. 米国の輸入港に到着した動物輸送船舶は，動物を 荷㧍ろしした後直ちに農務省獣医官の監督のもとに十分 な清掃消毒を行なう。またすべての乾草, わら, 敷料去 の他こ机準ずるものについても適当な処理を行なら.

\section{Bovine Parainfluenza Type III in Noto, Ishikawa Prefecture I. Outbreaks and Etiology}

T. YUSEN, S. Ishiguro and T. INAGuchi

(IshiKawa Prefectural Federation of Agricultural Mutual Aid Associations)

\section{SUMMARY}

About one thousand calves of the native Japanese breed on pasture were found infected with infections suppurative bronchopnenmonia in the Noto district, Ishikawa Prefecture, over a period from 1964 to 1968. Of them, 34 calves $(3 \%)$ succumbed or were condemned.

Etiological investigation revealed that they were cases of shipping fever induced by mixed infection with Type III parainfluenza virus, adenovirus, Pseudomonas aeruginosa, Proteus, Alcaligenes faecalis,
Escherichia coli, Haemophilus, and Alkalescens dispar. After an incubation period of about ten days, an infected calf manifested pyrexia, coughing, nasal discharge, mucous râle, and diarrhea. It took two weeks to more than a month for the calf to recover. Death occurred sometimes. Stress from changes in environment was an inportant factor to induce infection. Transmission was direct or indirect and mild. The infection might become enzootic and hard to control. 